\title{
Metody analizy i oceny ryzyka stosowane w zarządzaniu kryzysowym na poziomie gminnym
}

\section{Streszczenie}

W artykule poruszono zagadnienia zarządzania kryzysowego na poziomie gminy, co jest istotne wobec rosnącego znaczenia problematyki szybkiej reakcji jednostek administracji terytorialnej na zaistnienie sytuacji kryzysowej oraz prawidłowej oceny możliwości jej wystąpienia. Celem artykułu jest identyfikacja metod analizy i oceny ryzyka stosowanych oraz możliwych do zastosowania w ramach zarządzania kryzysowego na poziomie gminy. Przedstawione zostały potrzeby jednostek administracji terytorialnej w zakresie dokonywania oceny ryzyka. Zaprezentowano wyniki przeglądu stosowanych i możliwych do zastosowania metod pod kątem ich praktycznej użyteczności. Zostały również przedstawione najlepsze praktyki analizy i oceny ryzyka na świecie.

Słowa kluczowe: zarządzanie kryzysowe, metody analizy ryzyka, metody oceny ryzyka, dokumentacja zarządzania kryzysowego.

Klasyfikacja JEL: H12.

Urszula Kąkol, Politechnika Warszawska, Wydział Zarządzania, Katedra Systemów Zarządzania, ul. Narbutta 85, 02-524 Warszawa, e-mail: Urszula.Kakol@pw.edu.pl

Marcin Marczewski, e-mail: mmarczewski@resilia.pl 


\section{Wprowadzenie}

Celem artykułu jest przedstawienie wyników badań dotyczących metod analizy i oceny ryzyka na potrzeby zarządzania kryzysowego na poziomie gminnym. Badania umożliwiły identyfikację potrzeb jednostek administracji terytorialnej: gmin miejskich, miejsko-wiejskich i wiejskich, w aspekcie prawnym i organizacyjnym pod kątem dokonywania oceny ryzyka, oraz określenie stosowanych oraz możliwych do zastosowania metod analizy i oceny ryzyka na danym szczeblu. Prowadzone badania oparte zostały na analizie źródeł pierwotnych - gminnych planów zarządzania kryzysowego. Z perspektywy zarządzania kryzysowego miasta na prawach powiatu realizują zadania szczebla powiatowego, w tym tworzą powiatowe plany zarządzania kryzysowego, i z tego względu zostały pominięte w artykule. W ramach opracowania dokonano identyfikacji najlepszych praktyk stosowanych na świecie na podstawie przeglądu zagranicznych metodyk oceny ryzyka (analiza źródeł pierwotnych).

Zarządzanie kryzysowe w Polsce realizowane jest na pięciu poziomach: centralnym, resortowym, wojewódzkim, powiatowym i gminnym. Zadania zarządzania kryzysowego na danych poziomach wynikają z ustawy o zarządzaniu kryzysowym i zostały szeroko omówione w literaturze [Ficoń 2011, s. 156-164; Metodyka oceny... 2015, s. 124-146]. Brakuje natomiast informacji o praktycznym sposobie oceny ryzyka dokonywanej na danych poziomach, szczególnie na najniższym szczeblu administracyjnym. Niniejszy artykuł jest próbą uzupełnienia tej luki. Na podstawie sporządzonych planów zarządzania kryzysowego można stwierdzić, że gminy są jednostkami zdolnymi do przeprowadzania oceny ryzyka. Występują jednak niespójności i różnice w zakresie stosowania takich metod jak mapy zagrożeń i ryzyka oraz w sposobie szacowania ryzyka.

Niniejszy artykuł opiera się na wynikach analiz będących częścią projektu realizowanego w ramach umowy z Narodowym Centrum Badań i Rozwoju na wykonanie projektów w zakresie badań naukowych i projektów rozwojowych na rzecz obronności i bezpieczeństwa państwa przez Politechnikę Warszawską (Wydział Zarządzania) oraz Medcore Sp. z o.o. ${ }^{1}$

\footnotetext{
${ }^{1}$ Artykuł stanowi wynik realizacji projektu finansowanego ze środków NCBiR na podstawie zawartej umowy DOB-BIO/11/02/2015 z dnia 22 grudnia 2015 r. pn. „Wysokospecjalistyczna platforma wspomagająca planowanie cywilne i ratownictwo w administracji publicznej RP oraz w jednostkach organizacyjnych KSRG" realizowanej w ramach konsorcjum Politechnika Warszawska Wydział Zarządzania oraz Medcore Sp. z o.o. (konkurs nr 7/2015).
} 


\section{Zarządzanie kryzysowe na poziomie gminnym}

Ustawa z dnia 26 kwietnia 2007 r. o zarządzaniu kryzysowym definiuje zarządzanie kryzysowe jako „działalność organów administracji publicznej będącą elementem kierowania bezpieczeństwem narodowym, która polega na zapobieganiu sytuacjom kryzysowym, przygotowaniu do przejmowania nad nimi kontroli w drodze zaplanowanych działań, reagowaniu w przypadku wystąpienia sytuacji kryzysowych, usuwaniu ich skutków oraz odtwarzaniu zasobów i infrastruktury krytycznej” (art. 2).

Zarządzanie kryzysowe na poziomie gminnym realizują następujące jednostki i organy:

- wójt/ burmistrz/prezydent miasta - organ odpowiedzialny za zarządzanie kryzysowe w danej jednostce terytorialnej,

- gminny zespół zarządzania kryzysowego (GZZK) - organ pomocniczy wójta/burmistrza/prezydenta miasta powoływany w celu zapewnienia wykonywania zadań zarządzania kryzysowego,

- gminne centrum zarządzania kryzysowego (GCZK) - możliwe do powołania przez wójta / burmistrza / prezydenta miasta w celu realizacji zadań z zakresu zarządzania kryzysowego.

Zadania z zakresu zarządzania kryzysowego na poziomie gminnym realizuje wójt/burmistrz/prezydent miasta przy pomocy komórki organizacyjnej urzędu gminy (miasta) właściwej w sprawach zarządzania kryzysowego.

\section{Ocena ryzyka na poziomie gminnym w świetle aktów prawnych i dokumentacji zarządzania kryzysowego}

Dokumentacja zarządzania kryzysowego na poziomie gminnym obejmuje:

1) gminny plan zarządzania kryzysowego (GPZK), w tym:

- plan główny, zawierający: charakterystykę zagrożeń oraz ocenę ryzyka ich wystąpienia, w tym dotyczących infrastruktury krytycznej; zadania i obowiązki uczestników zarządzania kryzysowego w formie siatki bezpieczeństwa; zestawienie sił i środków planowanych do wykorzystania w sytuacjach kryzysowych;

- zespół przedsięwzięć na wypadek sytuacji kryzysowych;

- załączniki funkcjonalne planu głównego;

2) inne dokumenty, w tym wewnętrzne akty prawne.

Jednym z zadań z zakresu zarządzania kryzysowego jest przeprowadzanie oceny ryzyka. Na danym poziomie administracyjnym opracowywane są gminne 
plany zarządzania kryzysowego, co jest wymogiem ustawowym. Uwzględniają one aspekt oceny ryzyka i sporządzane są na wzór krajowego planu zarządzania kryzysowego (KPZK). Plany tworzone są przez komórkę organizacyjną urzędu miasta właściwą w sprawach zarządzania kryzysowego oraz opiniowane przez gminny zespół zarządzania kryzysowego. Podmiotem odpowiedzialnym jest organ zarządzania kryzysowego na szczeblu gminnym - wójt/burmistrz/prezydent miasta. Po opracowaniu są one przedkładane staroście do zatwierdzenia. $\mathrm{W}$ tabeli 1 przedstawiono zadania z zakresu oceny ryzyka na szczeblu gminnym zawarte w gminnym planie zarządzania kryzysowego (częstotliwość oceny ryzyka - cykl nie dłuższy niż 2 lata).

Tabela 1. Zadania z zakresu oceny ryzyka na szczeblu gminnym

\begin{tabular}{|l|l|l|}
\hline \multicolumn{1}{|c|}{ Organ/komórka } & \multicolumn{1}{|c|}{ Podstawa prawna } & \multicolumn{1}{c|}{$\begin{array}{c}\text { Zadania z zakresu oceny ryzyka na szczeblu } \\
\text { gminnym }\end{array}$} \\
\hline $\begin{array}{l}\text { Wójt/burmistrz/ } \\
\text { prezydent miasta }\end{array}$ & $\begin{array}{l}\text { [Ustawa z dnia } \\
26 \text { kwietnia 2007..., } \\
\text { art. 19 ust. 2] }\end{array}$ & $\begin{array}{l}\text { - podmiot odpowiedzialny za ocenę ryzyka } \\
- \text { podmiot realizujący zadania z zakresu pla- } \\
\text { nowania cywilnego, w tym: opracowywanie } \\
\text { i przedkładanie staroście do zatwierdzenia } \\
\text { GPZK }\end{array}$ \\
\hline $\begin{array}{l}\text { Komórka organiza- } \\
\text { cyjna urzędu gminy } \\
\text { (miasta) właściwa } \\
\text { w sprawach zarządza- } \\
\text { nia kryzysowego }\end{array}$ & $\begin{array}{l}\text { [Ustawa z dnia } \\
\text { art. 19 ust. 3] }\end{array}$ & $\begin{array}{l}\text { - podmiot prowadzący ocenę ryzyka } \\
- \text { podmiot realizujący zadania z zakresu pla- } \\
\text { nowania cywilnego, w tym: opracowywanie } \\
\text { i przedkładanie staroście do zatwierdzenia } \\
\text { GPZK }\end{array}$ \\
\hline $\begin{array}{l}\text { Gminny zespół zarzą- } \\
\text { dzania kryzysowego }\end{array}$ & $\begin{array}{l}\text { [Ustawa z dnia } \\
26 \text { kwietnia 2007..., } \\
\text { art. 19 ust. 4-5] }\end{array}$ & $\begin{array}{l}\text { - podmiot prowadzący ocenę ryzyka } \\
- \text { podmiot realizujący zadania: oceny wystę- } \\
\text { pujących i potencjalnych zagrożeń mogących } \\
\text { mieć wpływ na bezpieczeństwo publiczne } \\
\text { i prognozowanie tych zagrożeń; przygoto- } \\
\text { wywanie propozycji działań i przedstawianie } \\
\text { wójtowi/burmistrzowi/prezydentowi miasta } \\
\text { wniosków dotyczących wykonania, zmiany } \\
\text { lub zaniechania działań ujętych w GPZK; } \\
\text { opiniowanie GPZK }\end{array}$ \\
\hline
\end{tabular}

Źródło: opracowanie własne na podstawie [Zaawansowana metodyka... 2016, s. 145].

Ocena ryzyka dokonywana przez gminy powinna uwzględniać potrzeby gmin oraz ich ograniczenia. Potrzeby gmin związane są z wymogami prawnymi dokonywania oceny ryzyka - Ustawy z dnia 26 kwietnia 2007 r. o zarządzaniu kryzysowym, która określa konieczność cyklicznej oceny ryzyka w związku z opracowywaniem gminnych planów zarządzania kryzysowego. Ograniczenia gmin w zakresie dokonywania oceny ryzyka wynikają z limitu środków budżetowych możliwych do wykorzystania na dany cel oraz z braku wiedzy i doświad- 
czenia osób dokonujących oceny ryzyka. Istotne są także zasoby, którymi dysponuje dana gmina. W związku $\mathrm{z}$ tym metody oceny ryzyka stosowane na potrzeby zarządzania kryzysowego na poziomie gminnym powinny być rozwiązaniami prostymi, aby mogły zostać z powodzeniem wdrożone. W dalszej części pracy zaprezentowano metody analizy i oceny ryzyka stosowane na poziomie gminnym, wskazując na zaistniałe problemy i luki w ich wdrożeniu. Przedstawiono najlepsze praktyki zaczerpnięte z zagranicznych metodyk oceny ryzyka, możliwych do zastosowania w problematycznych obszarach oceny ryzyka na poziomie gminnym w Polsce.

\section{Metody analizy i oceny ryzyka stosowane na potrzeby zarządzania kryzysowego na poziomie gminnym w Polsce}

W ramach badań zostały zidentyfikowane metody analizy i oceny ryzyka stosowane na potrzeby zarządzania kryzysowego na poziomie gminnym. Prowadzone badania oparte zostały na analizie źródeł pierwotnych - gminnych planów zarządzania kryzysowego. Badania miały charakter badań wstępnych opartych na analizie studiów przypadków - przeanalizowano 20 przypadków. Badaniom poddano zarówno gminy miejskie (udział próby w badaniu 35\%), gminy wiejskie $(50 \%)$ oraz gminy miejsko-wiejskie (15\%). Poniżej przedstawiono zidentyfikowane metody analizy i oceny ryzyka oraz zakres ich stosowania.

\section{Praca zespołowa i udziat ekspertów}

Plany tworzone są przez komórkę organizacyjną urzędu miasta, właściwą w sprawach zarządzania kryzysowego, oraz opiniowane przez gminny zespół zarządzania kryzysowego. W przypadku oceny ryzyka dokonywanej na poziomie gminnym udział ekspertów jest nieznaczny. Przewiduje się zaangażowanie ekspertów w pracę nad oceną ryzyka, ale tylko w pojedynczym przypadku wymieniono ekspertów uczestniczących w pracach nad oceną ryzyka. Warto, aby osobami współpracującymi przy ocenie ryzyka były osoby wyznaczone przez interesariuszy zewnętrznych, którym przekazywana jest informacja o ocenie ryzyka, np. Straż Pożarną, Policję, inspektora nadzoru budowlanego, przedsiębiorstwa świadczące usługi komunalne.

\section{Metody identyfikacji zagrożeń}

Przegląd gminnych planów zarządzania kryzysowego pozwolił na wskazanie rozwiązań z zakresu sposobów identyfikacji zagrożeń. Najczęściej stosowanym rozwiązaniem jest identyfikacja zagrożeń na podstawie katalogu zagrożeń. Jako katalog zagrożeń przyjmowane są często zagrożenia wymienione w krajowym 
planie zarządzania kryzysowego. Ich wykaz zawarto w tabeli 2 . Rozwiązanie to powoduje, że gminne plany obejmują tylko przedstawione w katalogu zagrożenia, co jest podejściem niewłaściwym wobec zmiennej istoty ryzyka.

Tabela 2. Katalog zagrożeń

\begin{tabular}{|c|l|c|l|}
\hline Lp. & \multicolumn{1}{|c|}{ Zagrożenia zawarte w KPZK } & Lp. & \multicolumn{1}{|c|}{ Zagrożenia zawarte w KPZK } \\
\hline 1 & Powódź & 10 & Epizootie \\
\hline 2 & Epidemie & 11 & Epifitozy \\
\hline 3 & Skażenie chemiczne & 12 & Katastrofy budowlane \\
\hline 4 & $\begin{array}{l}\text { Zakłócenia w dostawach energii } \\
\text { elektrycznej }\end{array}$ & 13 & Osuwiska \\
\hline 5 & Zakłócenia w dostawach paliw płynnych & 14 & Susza \\
\hline 6 & Zakłócenia w dostawach gazu & 15 & Skażenia radiacyjne \\
\hline 7 & Silne mrozy/intensywne opady śniegu & 16 & Protesty społeczne \\
\hline 8 & Huragany & 17 & Zagrożenie terrorystyczne \\
\hline 9 & Pożary lasów & 18 & Zagrożenie cyberprzestrzeni \\
\hline
\end{tabular}

Źródło: [Krajowy Plan... 2013, s. 8-46].

W niektórych planach zarządzania kryzysowego zagrożenia grupowane są w kategorie, np.: zagrożenia atmosferyczne, zagrożenia skażeniami, zagrożenia epidemiologiczne, zagrożenia awariami w infrastrukturze, zagrożenia pożarami, zagrożenia katastrofami, zagrożenia społeczne i publiczne.

Zagrożenia zawarte $\mathrm{w}$ gminnych planach zarządzania kryzysowego są dosyć szczegółowo charakteryzowane. Charakterystyka zagrożeń ma formę opisową z częstą identyfikacją obszaru, jaki dane zagrożenie może objąć swym zasięgiem.

\section{Scenariusze zagrożeń}

Scenariusze zagrożeń nie są często stosowanym rozwiązaniem na poziomie gminnym (wystąpiły trzy przypadki zastosowania scenariuszy na 20 przeanalizowanych), pomimo że takie rozwiązanie jest stosowane na poziomie wojewódzkim i resortowym. Na szczeblu wojewódzkim i resortowym stosowanie scenariuszy zagrożeń wynika z Procedury opracowania raportu czastkowego [2010, s. 11] stworzonej przez RCB na potrzeby opracowania Raportu o zagrożeniach bezpieczeństwa narodowego.

W przypadku stosowania scenariuszy zagrożeń ich użycie było również niewłaściwe, ponieważ dokonano pogrupowania zagrożeń w kategorie, a same zagrożenia zostały określone mianem scenariuszy zagrożeń i były traktowane na równi z nimi. Właściwe stosowanie scenariuszy, które umożliwiają rozróżnienie różnych form rozchodzenia się i rozprzestrzeniania zagrożeń, jest rzadko spotykane (wystąpił jeden taki przypadek). 
Mapy zagrożeń

Zgodnie z definicją zawartą w ustawie o zarządzaniu kryzysowym mapa zagrożeń to mapa przedstawiająca obszar geograficzny objęty zasięgiem zagrożenia z uwzględnieniem różnych scenariuszy zdarzeń [Ustawa z dnia 26 kwietnia 2007..., art. 3 pkt 9].

Zastosowanie map zagrożeń jest szerokie, co związane jest z prostotą tego narzędzia, przy czym poszczególne mapy dotyczą tylko pojedynczych zagrożeń, a nie różnych scenariuszy zdarzeń. W tabeli 3 przedstawiono zestawienie map, jakie zidentyfikowano $\mathrm{w}$ gminnych planach zarządzania kryzysowego. Warto zauważyć, że w przypadku gmin, które miały dość dużo opracowanych map (powyżej 10), mapy te dotyczyły nie tylko gminy, ale całego powiatu. Można więc wyciągnąć wniosek, że zostały udostępnione z powiatowych planów zarządzania kryzysowego lub uzupełnione na etapie nanoszenia uwag i zaleceń przez starostę do gminnego planu.

Tabela 3. Rodzaje map zagrożeń

\begin{tabular}{|c|l|}
\hline Lp. & \multicolumn{1}{|c|}{ Rodzaj mapy zagrożenia } \\
\hline 1 & Zagrożenie powodziowe - podtopienia, zalania oraz obiekty ochrony przeciwpowodziowej \\
\hline 2 & Zagrożenie dużymi pożarami przestrzennymi lasów \\
\hline 3 & Zagrożenie pożarowe i wybuchowe \\
\hline 4 & Zagrożenie pożarowe dla obiektów zabytkowych \\
\hline 5 & Zagrożenie awarią elektrowni atomowej \\
\hline 6 & Zagrożenie katastrofami komunikacyjnymi \\
\hline 7 & Zakłócenia w dostawie energii \\
\hline 8 & Zakłócenia w dostawie gazu \\
\hline 9 & Zakłócenia w dostawie wody \\
\hline 10 & Trasy drogowe przewozu materiałów niebezpiecznych \\
\hline 11 & Linie kolejowe przewozu materiałów niebezpiecznych \\
\hline 12 & Szlaki komunikacyjne gminy \\
\hline 13 & Gazociągi na terenie gminy \\
\hline 14 & Lokalizacja zakładów zwiększonego ryzyka wystąpienia poważnej awarii przemysłowej \\
\hline 15 & Skażenie chemiczno-ekologiczne wzdłuż przebiegu tras drogowych i linii kolejowych \\
\hline 16 & Zagrożenie wystąpienia lub wystąpienie choroby zwierząt na terenie gminy \\
\hline 17 & Potencjalne źródła epidemii na terenie gminy \\
\hline 18 & Obiekty narażone na ataki terrorystyczne \\
\hline
\end{tabular}

Źródło: opracowanie własne. 
W gminnych planach najczęściej stosowane są mapy prezentujące zagrożenia powodziowe, pożarowe oraz mapy prezentujące trasy drogowe przewozu materiałów niebezpiecznych, linie kolejowe przewozu materiałów niebezpiecznych, szlaki komunikacyjne. Mapy te są stosowane ze względu na posiadanie odpowiednich danych, co wpływa na dużą łatwość w ich sporządzaniu.

\section{Mapa ryzyka}

Mapa ryzyka, zgodnie z definicją zawartą w ustawie o zarządzaniu kryzysowym, to mapa lub opis przedstawiający potencjalnie negatywne skutki oddziaływania zagrożenia na ludzi, środowisko, mienie i infrastrukturę [Ustawa z dnia 26 kwietnia $2007 .$. , art. 3 pkt 10].

Stosowanie graficznych map ryzyka jest ograniczone - dla zidentyfikowanych dwóch przypadków mapy ryzyka dotyczyły nie gmin, ale powiatów, co pozwala wyciągnąć wniosek, że zostały, podobnie jak mapy zagrożeń, udostępnione z powiatowych planów zarządzania kryzysowego. W przypadku map ryzyka przeważa opis przedstawiający możliwe negatywne skutki w razie wystąpienia zagrożenia. W niektórych gminnych planach zarządzania kryzysowego mapy ryzyka nie są przedstawiane.

\section{Metody szacowania ryzyka}

Szacowanie ryzyka polega na określeniu prawdopodobieństwa i skutku, a następnie określeniu wartości ryzyka przez stworzenie matrycy ryzyka. Warto zauważyć, że nie zawsze gminy określają wartość ryzyka lub też określają prawdopodobieństwo i skutek, nie podając końcowej oceny ryzyka. W gminnych planach zarządzania kryzysowego często brakuje również informacji na temat sposobu szacowania ryzyka - określona jest jego ostateczna wartość liczbowa, bez wskazania skali wartości ryzyka lub informacji o akceptowalności ryzyka. Tak podany wynik jest enigmatyczny dla odbiorcy raportu. Do oceny prawdopodobieństwa i skutków stosowane są metody jakościowe.

\section{Metody jakościowe określania prawdopodobieństwa}

Metody jakościowe określania ryzyka opierają się na ocenie w skali 3- lub 5-stopniowej oraz opisowej. Skala 5-stopniowa, którą posługują się gminy, została przejęta z Procedury opracowania raportu czastkowego [2010, s. 15], opracowanej przez RCB na potrzeby sporządzania Raportu o zagrożeniach bezpieczeństwa narodowego. W analizowanych przypadkach zaobserwowano, że skala 3-stopniowa jest uproszczeniem skali 5-stopniowej. W porównaniu ze skalą 5-stopniową w skali 3-stopniowej nie występują graniczne wartości prawdopodobieństwa: wystąpienia zdarzenia raz na 500 lat oraz wystąpienia zdarzenia raz na rok lub częściej. 
Metody jakościowe określania skutków wystapienia zagrożenia

Metody jakościowe określania skutków wystąpienia zagrożenia opierają się na ocenie w skali 3- lub 5-stopniowej oraz opisowej. Analizy dokonuje się głównie dla kategorii:

- życie i zdrowie (Z),

- mienie wraz z infrastrukturą (M),

- środowisko (S).

Tak samo jak w przypadku oceny prawdopodobieństwa skala 3-stopniowa jest uproszczeniem skali 5-stopniowej ze względu na pominięcie wartości granicznych. Natomiast skala 5-stopniowa została przejęta z Procedury opracowania raportu czastkowego [2010, s. 15-16].

Matryce ryzyka

Matryce ryzyka umożliwiają odczytanie wartości oceny ryzyka. Jak wspomniano we wcześniejszej części artykułu, gminy nie zawsze dokonują oceny ryzyka - określają prawdopodobieństwo i skutek, nie podając końcowej oceny ryzyka. W innych przypadkach podawana jest ostateczna wartość liczbowa ryzyka bez wskazania skali wartości ryzyka lub też informacji o akceptowalności ryzyka.

W przypadku dokonywania oceny prawdopodobieństwa i skutków za pomocą wcześniej omówionych metod jakościowych gminy stosują matryce ryzyka. Pokazują one zależność między prawdopodobieństwem a skutkami. W przypadku stosowania skal 3-stopniowych do oceny prawdopodobieństwa i skutków ryzyka matryca pozwala zidentyfikować trzy rodzaje wartości ryzyka (tabela 4):

- małe (kolor niebieski),

- średnie (kolor zielony),

- duże (kolor czerwony).

Tabela 4. Matryca ryzyka dla skali 3-stopniowej

\begin{tabular}{|c|c|c|c|c|c|}
\hline \multirow{2}{*}{ Prawdopodobieństwo } & 1 & wysokie & & \\
\cline { 2 - 6 } & 2 & średnie & & & \\
\cline { 2 - 6 } & 3 & niskie & & & \\
\hline \multirow{2}{*}{ Wartość ryzyka } & A & B & C \\
\cline { 4 - 6 } & & małe & średnie & duże \\
\cline { 4 - 6 } & & \multicolumn{3}{|c|}{ Skutki } \\
\hline
\end{tabular}

Źródło: opracowanie własne. 
W przypadku stosowania skal 5-stopniowych do oceny prawdopodobieństwa i skutków ryzyka matryca pozwala zidentyfikować pięć rodzajów wartości ryzyka (tabela 5):

- minimalne (kolor niebieski),

- małe (kolor zielony),

- średnie (kolor żółty),

- duże (kolor czerwony),

- ekstremalne (kolor brunatny).

Zastosowany podział jest zgodny z Procedura opracowania raportu cząstkowego [2010, s. 17], stosowaną na potrzeby opracowania Raportu o zagrożeniach bezpieczeństwa narodowego.

Tabela 5. Matryca ryzyka dla skali 5-stopniowej

\begin{tabular}{|c|c|c|c|c|c|c|c|}
\hline \multirow{5}{*}{$\begin{array}{l}\text { Prawdopodo- } \\
\text { bieństwo }\end{array}$} & 5 & $\begin{array}{l}\text { bardzo prawdo- } \\
\text { podobne }\end{array}$ & & & & & \\
\hline & 4 & $\begin{array}{l}\text { prawdo- } \\
\text { podobne }\end{array}$ & & & & & \\
\hline & 3 & możliwe & & & & & \\
\hline & 2 & rzadkie & & & & & \\
\hline & 1 & bardzo rzadkie & & & & & \\
\hline \multirow{3}{*}{\multicolumn{3}{|c|}{ Wartość ryzyka }} & nieistotne & małe & średnie & duże & $\begin{array}{l}\text { katastro- } \\
\text { falne }\end{array}$ \\
\hline & & & A & B & $\mathrm{C}$ & $\mathrm{D}$ & $\mathrm{E}$ \\
\hline & & & \multicolumn{5}{|c|}{ Skutki } \\
\hline
\end{tabular}

Źródło: opracowanie na podstawie [Procedura opracowania... 2010, s. 17].

Ocena akceptowalności ryzyka

W większości dokonywanych ocen brakuje informacji na temat akceptowalności ryzyka. Przykładowe poziomy akceptowalności ryzyka, które zastosowano przy ocenie ryzyka na poziomie gminnym, podano w tabeli 6 . Zawarto w niej również charakterystykę poszczególnych poziomów ryzyka pochodzącą z Procedury opracowania raportu cząstkowego [2010, s. 18]. Należy przy tym dodać, że poszczególne gminy powinny ustalać dla każdego ryzyka z osobna poziom jego akceptowalności, a także że dany poziom akceptowalności nie musi być przyporządkowany konkretnej wartości ryzyka na stałe. 
Tabela 6. Poziomy akceptowalności ryzyka

\begin{tabular}{|c|c|c|}
\hline Wartość ryzyka & $\begin{array}{c}\text { Poziom akceptowalności } \\
\text { ryzyka }\end{array}$ & Charakterystyka \\
\hline Minimalne & Akceptowalne (A) & \multirow{2}{*}{$\begin{array}{l}\text { - nie są wymagane żadne dodatkowe środki bez- } \\
\text { pieczeństwa } \\
\text { - akceptowane są aktualne rozwiązania i przypi- } \\
\text { sane im siły i środki, działania monitorujące }\end{array}$} \\
\hline Małe & Akceptowalne (A) & \\
\hline Średnie & Tolerowane (T) & $\begin{array}{l}\text { - należy dokonać oceny alternatyw, czy wpro- } \\
\text { wadzenie niewielkich zmian organizacyjnych, } \\
\text { prawnych bądź funkcjonalnych nie przyczyni } \\
\text { się do poprawy bezpieczeństwa lub poczucia } \\
\text { bezpieczeństwa }\end{array}$ \\
\hline Duże & $\begin{array}{l}\text { Warunkowo tolerowane } \\
\text { (WT) }\end{array}$ & $\begin{array}{l}\text { - należy wprowadzić dodatkowe środki bezpie- } \\
\text { czeństwa w terminie do } 6 \text { miesięcy } \\
\text { - należy ulepszyć stosowane rozwiązania }\end{array}$ \\
\hline Katastrofalne & Nieakceptowane (N) & $\begin{array}{l}\text { - należy podjąć natychmiastowe działania w celu } \\
\text { zwiększenia bezpieczeństwa, wprowadzić dodat- } \\
\text { kowe/nowe rozwiązania }\end{array}$ \\
\hline
\end{tabular}

Źródło: opracowanie własne na postawie [Procedura opracowania... 2010, s. 18].

Wnioski z przegladu metod analizy i oceny ryzyka stosowanych na potrzeby zarzadzania kryzysowego na poziomie gminnym w Polsce

Podsumowując przegląd metod analizy i oceny ryzyka stosowanych na poziomie gminnym w Polsce, można stwierdzić, że głównymi problemami są:

- brak umiejętności tworzenia scenariuszy zdarzeń,

- brak oceny ryzyka lub niepełna informacja o ocenie ryzyka,

- brak umiejętności tworzenia graficznej reprezentacji map ryzyka,

- brak informacji o akceptowalności ryzyka,

- brak metod analitycznych stosowanych w procesie oceny ryzyka.

Zauważono również, że nie we wszystkich planach występuje opis gminy prezentujący dane terytorialne, demograficzne oraz informacje o infrastrukturze, który może pomagać w procesie oceny ryzyka. Opisy te nie są ustandaryzowane, co skutkuje znacznymi różnicami jakościowymi między opisami z różnych gmin. Różnice w poziomach jakościowych występują w opisach zagrożeń i w stworzonych scenariuszach zdarzeń (o ile takie opracowano).

Widoczne różnice spowodowane są brakiem jednolitej metodyki analizy i oceny ryzyka opartej na podejściu analitycznym. Propozycję zaawansowanej metodyki oceny ryzyka w publicznym zarządzaniu kryzysowym, zawierającej kompleksowe podejście do oceny ryzyka i wykorzystującej aspekty zarządzania wiedzą, zawarto w publikacji opracowanej w ramach pracy badawczej pracowników Wydziału Zarządzania Politechniki Warszawskiej, prowadzonej w ramach 
umowy z NCBiR z konkursu 3/2012 na wykonanie projektów w zakresie badań naukowych i projektów rozwojowych na rzecz obronności i bezpieczeństwa państwa, przez konsorcjum: Akademia Obrony Narodowej, Centrum Naukowo-Badawcze Ochrony Przeciwpożarowej, Politechnika Warszawska (Wydział Zarządzania), Szkoła Główna Służby Pożarniczej i Medcore Sp. z o.o. [Zaawansowana metodyka... 2016]. Aktualnie trwają badania nad autorską metodą oceny ryzyka w zarządzaniu kryzysowym w jednostkach administracji terytorialnej, która opiera się na analitycznym podejściu do określania poziomu ryzyka. Jedną z przesłanek do podjęcia tych badań były opisane powyżej problemy występujące $\mathrm{w}$ praktyce $\mathrm{w}$ procesie oceny ryzyka.

\section{Najlepsze praktyki w zakresie analizy i oceny ryzyka stosowane w innych krajach}

Przeglad modeli i metodyk kompleksowej oceny ryzyka stosowanych $w$ wybranych krajach

W dalszej części artykułu zaprezentowano wyniki przeglądu modeli i metodyk kompleksowej oceny ryzyka stosowanych w wybranych krajach. Przegląd miał na celu identyfikację najlepszych praktyk możliwych do zastosowania w problematycznych obszarach oceny ryzyka na poziomie gminnym w Polsce.

Proces zarządzania ryzykiem na potrzeby planowania cywilnego, ratowniczego i kryzysowego realizowany jest w wielu krajach. Do prezentacji w niniejszym opracowaniu wybrano metodyki zarządzania i oceny ryzyka krajów, które mają duże doświadczenie w stosowaniu rozwiązań w tym zakresie:

- USA - Multi Hazard Identification and Risk Assessment (MHIRA) [1997],

- Kanady - All Hazards Risk Assessment Methodology (AHRA) [2012],

- Danii - DEMA's Model for Risk and Vulnerability Analysis (RVA model) [2006],

- Irlandii - A National Risk Assessment for Ireland [2012],

- Republiki Federalnej Niemiec - Method of Risk Analysis for Civil Protection [2011].

W związku z tym, że zagraniczne metodyki zostały już szeroko omówione w literaturze [Zarzadzanie ryzykiem... 2015, s. 151-269; Pamięć przyszłości... 2015, s. 117-158; Metodyka oceny... 2015, s. 21-47; Zaawansowana metodyka... 2016, s. 247 i 268], w niniejszym opracowaniu skupiono się na opisie metod, technik oraz narzędzi wykorzystywanych na potrzeby analizy i oceny ryzyka w kontekście zidentyfikowanych luk w ocenie ryzyka na poziomie gminnym w Polsce. 
Ustandaryzowany opis obszaru podlegajacego analizie ryzyka

Ustandaryzowany opis obszaru podlegającego analizie ryzyka występuje w metodykach niemieckiej, irlandzkiej i kanadyjskiej. W tabeli 7 przedstawiono parametry charakteryzujące analizowany obszar zgodnie z metodyką niemiecką Method of Risk Analysis for Civil Protection. Zaproponowany sposób opisu jest prostym rozwiązaniem - wprowadza pięć głównych kategorii opisu: ludność, środowisko, gospodarkę, zaopatrzenie i wartości niematerialne. Wskazuje również możliwe źródła pozyskiwania informacji, co znacznie ułatwia opracowanie opisu obszaru.

Tabela 7. Kategorie opisu obszaru podlegającego analizie ryzyka w metodyce niemieckiej

\begin{tabular}{|c|c|c|}
\hline Kategoria & Informacja & Możliwe źródła informacji \\
\hline Ludność & $\begin{array}{l}\text { - liczba mieszkańców } \\
\text { - gęstość zaludnienia } \\
\text { - liczba gospodarstw domowych }\end{array}$ & $\begin{array}{l}\text { - biura statystyczne } \\
\text { - rejestry populacji }\end{array}$ \\
\hline \multirow[t]{2}{*}{ Środowisko } & - obszary chronione & $\begin{array}{l}\text { - ministerstwo właściwe ds. ochrony środo- } \\
\text { wiska } \\
\text { - biura ochrony środowiska }\end{array}$ \\
\hline & - obszary rolne & $\begin{array}{l}\text { - biura statystyczne } \\
\text { - ministerstwo właściwe ds. rolnictwa }\end{array}$ \\
\hline Gospodarka & $\begin{array}{l}\text { - wyniki gospodarcze } \\
\text { - wpływy podatkowe }\end{array}$ & $\begin{array}{l}\text { - biura statystyczne } \\
\text { - władza administracyjna właściwa ds. eko- } \\
\text { nomicznych }\end{array}$ \\
\hline Zaopatrzenie & $\begin{array}{l}\text { - infrastruktura dostawy wody } \\
\text { - infrastruktura dostawy energii } \\
\text { elektrycznej } \\
\text { - infrastruktura dostawy gazu } \\
\text { - infrastruktura dostawy usług } \\
\text { telekomunikacyjnych }\end{array}$ & $\begin{array}{l}\text { - władza administracyjna właściwa ds. eko- } \\
\text { nomicznych } \\
\text { - dostawcy }\end{array}$ \\
\hline $\begin{array}{l}\text { Wartości } \\
\text { niematerialne }\end{array}$ & - dobra kulturowe & $\begin{array}{l}\text { - władza administracyjna właściwa ds. kon- } \\
\text { serwacji zabytków }\end{array}$ \\
\hline
\end{tabular}

Źródło: opracowanie własne na podstawie [Method of Risk... 2011, s. 24].

\section{Scenariusz zdarzeń}

Scenariusze zdarzeń stosowane są w metodykach amerykańskiej, duńskiej, niemieckiej i kanadyjskiej. Poniżej przedstawiono sposób tworzenia scenariusza zdarzeń zgodnie z metodyką kanadyjską All Hazards Risk Assessment Methodology. Scenariusze zdarzeń w danej metodyce cechują się bardzo dużą szczegółowością, co umożliwia wyeliminowanie nieprecyzyjnych założeń i niepewności 
i ma znaczący wpływ na dokładność wyników analizy ryzyka. W tabeli 8 przedstawiono przykładowy formularz opisu scenariusza.

Tabela 8. Opis scenariusza zdarzenia według metodyki AHRA

\begin{tabular}{|c|c|}
\hline \multicolumn{2}{|r|}{ Składowe scenariusza zdarzenia } \\
\hline Opis scenariusza & $\begin{array}{l}\text { - nazwa scenariusza zdarzenia/tytuł } \\
\text { - kod zagrożenia dla zdarzenia głównego } \\
\text { - kod zagrożenia dla zdarzenia wtórnego } \\
\text { - jednostka główna } \\
\text { - jednostki wspierające } \\
\text { - kluczowe źródła informacji nt. scenariusza zdarzenia }\end{array}$ \\
\hline $\begin{array}{l}\text { Opis scenariusza } \\
\text { zdarzenia }\end{array}$ & $\begin{array}{l}\text { - opis zdarzenia (kontekst, przyczyna, źródło, natura, skala) } \\
\text { - ścieżka zdarzeń prowadzących do zdarzenia (incydenty pośrednie) } \\
\text { - informacje geograficzne (lokalizacja, region itp.) } \\
\text { - naturalne środowisko } \\
\text { - warunki meteorologiczne } \\
\text { - sezonowość } \\
\text { - charakterystyka zagrożenia } \\
\text { - informacje o podatności obszaru na wystąpienie zagrożeń } \\
\text { (kontekst, populacja, gęstość zaludniena, poziom urbanizacji, } \\
\text { kluczowa infrastruktura, informacje ekonomiczne, polityczne itp.) } \\
\text { - inne ważne wnioski i założenia } \\
\text { - niepewność w opisie scenariusza zdarzenia }\end{array}$ \\
\hline $\begin{array}{l}\text { Ocena } \\
\text { prawdopodobieństwa }\end{array}$ & $\begin{array}{l}\text { - czas/horyzont czasowy, w którym zdarzenie może wystąpić } \\
\text { - niepewność w ocenie prawdopodobieństwa }\end{array}$ \\
\hline Ocena skutków & $\begin{array}{l}\text { - kategorie oceny: ludzie, gospodarka, środowisko, bezpieczeństwo } \\
\text { terytorialne, reputacja kraju, społeczeństwo } \\
\text { - niepewność w ocenie wpływu }\end{array}$ \\
\hline $\begin{array}{l}\text { Wstępne planowanie } \\
\text { postępowania } \\
\text { z ryzykiem }\end{array}$ & $\begin{array}{l}\text { - podstawowy plan postępowania z ryzykiem (działania związane } \\
\text { z postępowaniem, harmonogramy, gotowość itp.) } \\
\text { - mierniki wdrożonych działań związanych z postępowaniem } \\
\text { z ryzykiem } \\
\text { - poziom, do którego ryzyko (prawdopodobieństwo i skutki) mogą } \\
\text { być zredukowane w wyniku planu postępowania } \\
\text { - dodatkowe zasoby niezbędne do postępowania z ryzykiem }\end{array}$ \\
\hline
\end{tabular}

Źródło: [All Hazards Risk... 2012, s. 66-69].

Ocena ryzyka i akceptowalność poziomów ryzyka

Ocena ryzyka w metodykach zagranicznych opiera się na macierzach ryzyka, które przedstawiają zależność między prawdopodobieństwem a skutkiem. Prawdopodobieństwo oraz skutek liczone są w skali 4- lub 5-stopniowej. Stosowane w Polsce rozwiązania są zbliżone. Natomiast określenie poziomów akceptowalności nie jest szeroko stosowane w rozwiązaniach zagranicznych. 
Graficzna prezentacja map ryzyka

Wyniki w zagranicznych metodykach prezentowane są głównie w postaci macierzy ryzyka oraz macierzy ryzyka z zaznaczonymi liniami izoryzyka. Graficzne mapy ryzyka nie są powszechnie stosowane. Wzorcowym przykładem wykorzystania map ryzyka są Stany Zjednoczone. Warto zaznaczyć, że w danym przypadku metodyka Multi Hazard Identification and Risk Assessment jest wspomagana oprogramowaniem (najnowsza wersja to Hazus-MH 3.1), które umożliwia analizę zagrożeń spowodowanych powodziami, huraganami i trzęsieniami ziemi. Oprogramowanie Hazus-MH wsparte jest rozwiązaniami typu GIS (geographic information systems), co umożliwia estymowanie zasięgu przestrzennego potencjalnych oraz zaistniałych zdarzeń.

\section{Zakończenie}

Wyniki badań dotyczących metod analizy i oceny ryzyka na potrzeby zarządzania kryzysowego na poziomie gminnym umożliwiły wskazanie stosowanych metod. Dokonano krytycznej analizy rozwiązań z zakresu oceny ryzyka wykorzystywanych na najniższym szczeblu administracyjnym. Zidentyfikowano problemy związane z nieumiejętnością tworzenia scenariuszy zdarzeń oraz nieustandaryzowanym opisem obszaru podlegającego analizie ryzyka. W odniesieniu do wspomnianych problemów wskazano najlepsze praktyki stosowane w innych krajach.

$\mathrm{W}$ przypadku występujących na poziomie gminnym problemów z określeniem wartości ryzyka i brakiem informacji o akceptowalności ryzyka gminy powinny czerpać wzorce np. z Krajowego Planu Zarządzania Kryzysowego 2013-2015. Jeśli chodzi o tworzenie graficznych prezentacji map ryzyka gminy są ograniczone brakiem odpowiednich środków np. na zakup zaawansowanych systemów GIS.

$\mathrm{W}$ ramach oceny ryzyka gminy leżące w obszarach przygranicznych umieszczają informacje o transgraniczności ryzyka. Jest to zgodne z podejściem prezentowanym w Dyrektywie Rady 2008/114/WE z dnia 8 grudnia 2008 r. w sprawie rozpoznawania i wyznaczania europejskiej infrastruktury krytycznej (EIK) oraz oceny potrzeb w zakresie poprawy jej ochrony, która na szczeblu centralnym nakłada obowiązek przekazywania innym państwom członkowskim informacji o potencjalnej EIK, której zakłócenie lub zniszczenie miałoby istotny wpływ na dane państwo członkowskie.

Warto rozszerzyć to podejście o identyfikację ryzyka nie tylko transgranicznego dla gmin przygranicznych, ale również o identyfikację ryzyka o zasięgu ponadlokalnym dla wszystkich gmin. Powinny zostać wypracowane mechanizmy umożliwiające przekazywanie innym gminom dokonującym oceny ryzyka informacji o zagrożeniu ponadlokalnym, które będzie wpływało na gminy sąsiednie. 


\section{Literatura}

All Hazards Risk Assessment Methodology Guidelines 2012-2013 [2012], Public Safety Canada, https://www.publicsafety.gc.ca/cnt/rsrcs/pblctns/ll-hzrds-ssssmnt/ll-hzrds-ssssmnt-eng.pdf (data dostępu: 18.07.2016).

Dyrektywa Rady 2008/114/WE z dnia 8 grudnia 2008 r. w sprawie rozpoznawania i wyznaczania europejskiej infrastruktury krytycznej oraz oceny potrzeb w zakresie poprawy jej ochrony, Dz.U.UE.L.2008.345.75.

Ficoń K. [2011], Logistyka kryzysowa. Procedury, potrzeby, potencjat, BEL Studio, Warszawa.

Introduction and User Guide DEMA's Model for Risk and Vulnerability Analysis [2006], Danish Emergency Management Agency, http://brs.dk/eng/inspection/contingency_ planning/rva/Pages/vulnerability_analysis_model.aspx (data dostępu: 18.07.2016).

Krajowy Plan Zarządzania Kryzysowego 2013-2015 [2013], Rządowe Centrum Bezpieczeństwa, Warszawa.

Method of Risk Analysis for Civil Protection [2011], Federal Office of Civil Protection and Disaster Assistance, Bonn, http:/www.bbk.bund.de/SharedDocs/Downloads/ BBK/EN/booklets_leaflets/Method_of_\%20Risk_Analysis.pdf?_blob=publicationFile (data dostępu: 18.07.2016).

Metodyka oceny ryzyka na potrzeby systemu zarzadzania kryzysowego RP [2015], red. W. Skomra, BEL Studio, Warszawa.

Multi Hazard Identification and Risk Assessment. A Cornerstone of the National Mitigation Strategy [1997], The Federal Emergency Management Agency's, https://www. fema.gov/media-library/assets/documents/7251 (data dostępu: 18.07.2016).

A National Risk Assessment for Ireland [2012], Office of Emergency Planning, https:// emergencyplanning.ie/media/docs/A\%20National\%20Risk\%20Assessment\%20 for\%20Ireland\%20Published.pdf (data dostępu: 18.07.2016).

Pamięć przyszłości. Analiza ryzyka dla zarządzania kryzysowego [2015], red. A. Abgarowicz, CNBOP-PIB, Józefów.

Procedura opracowania raportu cząstkowego [2010], Rządowe Centrum Bezpieczeństwa, Warszawa.

Ustawa z dnia 26 kwietnia 2007 r. o zarządzaniu kryzysowym, tekst jedn. Dz.U. z 2013 r. poz. 1166 z późn. zm.

Zaawansowana metodyka oceny ryzyka w publicznym zarzadzaniu kryzysowym [2016], red. A. Kosieradzka, J. Zawiła-Niedźwiecki, Edu-Libri, Kraków-Legionowo.

Zarzadzanie ryzykiem. Przeglad wybranych metodyk [2015], red. D. Wróblewski, CNBOP-PIB, Józefów.

\section{Crisis Management, Risk Analysis and Assessment Methods on the Municipal Level}

(Abstract)

This article examines crisis management on the municipal level. The rapid reaction of territorial administration units to crisis and the correct assessment of the possibility of it occurring is more and more important. The goal of the article is to identify the 
risk analysis and assessment methods which are or could be used for crisis management purposes on the municipal level. The risk assessment needs of territorial administration units are defined and the survey results of practical utility of risk analysis and assessment methods is presented. The best risk analysis and assessment practices in the world are also discussed.

Keywords: crisis management, risk analysis methods, risk assessment methods, crisis management documentation. 